\title{
Perencanaan Komunikasi Pemerintah Kota Palembang dalam Kampanye Program Palembang EMAS (Elok, Madani, Aman, Sejahtera)
}

\author{
Mutia Dewi \\ Dosen Program Studi Ilmu Komunikasi Universitas Islam Indonesia \\ M. Masri Hadiwijaya \\ Alumnus Program Studi Ilmu Komunikasi Universitas Islam Indonesia
}

\begin{abstract}
Abstrak
Perencanaan komunikasi merupakan aktivitas yang tak terpisahkan dalam program komunikasi maupun program-program pembangunan yang memerlukan dukungan komunikasi, termasuk dalam mem-branding Kota. Sebagai salah satu bentuk kegiatan memasarkan Kota, aktivitas ini tidak luput dari perencanaan komunikasi. Oleh karena itu, tulisan ini akan mengkaji aktivitas perencanaan komunikasi yang dilakukan oleh pemerintah Kota Palembang dalam mengkampanyekan program Palembang EMAS.

Penelitian ini menggunakan metode penelitian kualitatif, yang berusaha menggambarkan atau mendeskripsikan objek yang diteliti berdasarkan fakta yang ada di lapangan. Data diperoleh melalui wawancara mendalam dengan asisten pemerintah bidang Humas dan protokol, Badan Perencanaan Pembangunan Daerah Tingkat II Kota Palembang, dan Dinas Komunikasi dan Informatika. Studi ini menemukan bahwa perencanaan komunikasi yang dilakukan oleh Pemerintah Kota Palembang dalam kampanye Palembang EMAS dilakukan melibatkan dua hal pokok, yaitu (1) organisasi yang menggerakkan kegiatan dalam hal ini pemerintah Kota dengan melakukan analisis dan riset, perumusan kebijakan, perencanaan program pelaksanaan dan kegiatan komunikasi; (2) publik yang menjadi sasaran kegiatan yang terdiri atas respon dan evaluasi dari masyarakat.
\end{abstract}

Kata Kunci : Perencanaan Komunikasi ,Program Komunikasi, Palembang EMAS.

\begin{abstract}
Communication planning is an inseparable activity in both the communication program and the development program such as the city branding program. As a city marketing program, the activity of city branding is inseparable from communication planning. This study aims to describe communication planning activity carried out by the government of Palembang City in campaigning Palembang EMAS program as the brand of Palembang city. The research was conducted by a qualitative method and relied on the field data gathered from formal sources such as from government assistant of public relations and protocols, Development Planning Agency Regional Level 2, and region officer of Department of Communication and Informatics. The research reveals that the Government communication planning in campaigning Palembang EMAS is conducted through two methods. The first method is organizing. This method was conducted by doing research and analysis, formulating policy, and planning of communication activity. The second method is arranging public as the target of the program by covering public responses and community evaluation toward the program.
\end{abstract}

Keywords : Communication Planning, Communication Program, Palembang EMAS 


\section{PENDAHULUAN}

Undang-undang no. 32 tahun 2004 tentang otonomi daerah menyebutkan bahwa kota-kota yang ada di Indonesia harus mampu meningkatkan Pendapatan Asli Daerah (PAD). Oleh karenanya, setiap daerah diberikan otonomi dengan tujuan meningkatkan kesejahteraan masyarakat melalui potensi daerah sekaligus menopang perekomonian Negara. Amanah tersebut mendorong kota-kota yang ada di Indonesia berlomba-lomba untuk memasarkan kotanya, baik untuk menarik investor maupun wisatawan sehingga memberikan penghasilan kepada kota tersebut.

Bagi kota yang memiliki sejumlah tempat wisata ataupun potensi yang bisa dijual, tidak akan sulit untuk menambah pendapatan daerahnya. "Bali", misalnya, tanpa perlu mengeluarkan energi lebih untuk "menjual" kotanya, wisatawan tetap akan datang dalam jumlah besar sehingga tidak mengherankan jika bagi wisatawan asing Indonesia adalah Bali. Meskipun Indonesia tidak hanya Bali, tetapi persepsi mengenai destinasi pariwisata Bali sebagai satu-satunya tempat wisata di Indonesia sulit untuk diubah. Ini karena Bali menawarkan value yang berbeda, dimana Bali itu sendiri telah dijadikan sebuah brand pariwisata dengan menawarkan budaya, pariwisata, kesenian dan kesenangan lainnya (Bungin, 2015: 69).

Fenomena di atas berbeda dengan kota-kota lain di Indonesia. Sejauh pengamatan penulis, semenjak diberlakukannya undang-undang otonomi daerah 2004, kota-kota di Indonesia mulai berusaha menggali potensi daerah demi meningkatkan pendapatan daerahnya. Pada 2007, beberapa Kota di
Indonesia semakin menggeliat untuk membuat brand kota seperti Kota Bandung. Semenjak 2007, Kota Bandung telah memposisikan dirinya sebagai Kota Kreatif (Dewi, 2016). Hanya saja, merek Bandung sebagai kota kreatif tidak terasa. Ini disebabkan belum sungguh-sugguhnya pemerintah saat itu dalam mengelola merek kota. Pada masa Ridwan Kamil, merek Bandung sebagai kota kreatif mulai gencar dilakukan. Salah satunya dengan merevitalisasi sudut kota dengan pembangunan sejumlah taman tematik, penyelenggaraan event dan festival, menguatkan ekonomi kreatif warga hingga bekerja sama dengan Kementrian Pariwisata Republik Indonesia untuk mendaftarkan Kota Bandung sebagai salah satu jaringan kota kreatif di dunia versi Unesco. Selanjutnya, pada bulan Desember 2015, Kota Bandung terpilih dan diakui sebagai salah satu jaringan kota kreatif dunia versi Unesco yang sejajar dengan kota-kota kreatif seperti Singapura, Budapest, Detroit (AS), dan Puebla di Mexico.

Melihat fenomena di atas, tidak heran jika perjalanan panjang mendesain sebuah merek kota bukanlah perkara mudah. Perlu memahami hakikat sebuah merek bagi kota hingga menyadari potensi kota sebagai sebuah ruh dalam merek yang akan dihasilkan. Ibarat merek sebuah produk, kota pun harus memiliki merek yang kuat sehingga orang mengenal kota tersebut berbeda dengan kota lainnya. Inilah salah satu tantangan kampanye komunikasi sebagai hakikat kajian perencanaan komunikasi. Dalam konteks tersebut, tidak saja menciptakan brand, tetapi juga bagaimana brand tersebut berhasil di pasaran dan memberikan efek domino. 
Berangkat dari kenyataan tersebut, peneliti tertarik untuk melihat perencanaan komunikasi yang dilakukan oleh Kota Palembang dengan kampanye brand Palembang EMAS. Pilihan Palembang didasari latar belakang bahwa Kota Palembang sebagai salah satu kota di Indonesia, bersama dengan Kota Jakarta, akan menjadi tuan rumah penyelenggaraan Asian Games tahun 2018. Sebagai titik awal penelitian ini, peneliti berpandangan bahwa Kota Palembang seyogianya memanfaatkan peristiwa ini sebagai sarana kampanye merek Palembang EMAS. Selain itu, peneliti juga tertarik untuk mengetahui perjalanan panjang brand Kota Palembang yang sering berubah seiiring dengan bergantinya pimpinan dan kebijakan mulai dari slogan yang mengusung Palembang Kota Air, Palembang Kota Sungai, dsb. Hal ini akan menjadi analisis kritis tersendiri bagi peneliti. Selain itu, ketertarikan peneliti pada Kota Palembang bahwa ketika Kota Palembang menggunakan kata EMAS dalam mem-branding kota nya. Ini karena istilah penggunaan kata EMAS identik dengan megah dan mewah. Namun, penelitian awal yang penulis lakukan menemukan bahwa EMAS bukan menunjukkan kemewahan ataupun kemegahan seperti yang asumsi awalnya, melainkan EMAS di sini merupakan singkatan dari Elok, Madani, Aman, dan Sejahtera. Hal ini tentu bukan sekedar merek yang muncul tiba-tiba, melainkan melewati proses perencanaan komunikasi yang panjang.

Perencanaan komunikasi dipilih sebagai kajian dalam penelitian ini karena yang disorot adalah kampanye Palembang EMAS sebagai sebuah brand Kota
Palembang. Observasi awal yang telah dilakuka oleh peneliti, mendapatkan bahwa Palembang EMAS tidak hanya menjadi sebuah brand kota, melainkan juga menjadi landasan pembangunan pemerintah yang tertuang pada visi misi pembangunan. Brand memiliki sifat untuk disiarkan kepada publik. Ini menandakan bahwa brand memiliki sifat publisitas dan karena itulah brand berada dalam lingkaran proses komunikasi. Oleh karena itu, melalui penelitian ini, peneliti ingin melihat Palembang EMAS sebagai sebuah program pembangunan, produk dan kampanye merek dengan melibatkan berbagai sumber daya komunikasi untuk keberhasilan program tersebut.

\section{Konsep Perencanaan Komunikasi}

Secara sederhana, perencanaan komunikasi berasal dari kata perencanaan dan komunikasi yang dapat didefenisikan sebagai proses pengimplementasian kebijakan komunikasi. Dalam kaita ini, ada dua konsep dasar yang memiliki perbedaan, tetapi saling berkaitan, yaitu perencanaan dan komunikasi. Perencanaan dilihat dari aspek manajemennya, sedangkan komunikasi dilihat proses penyebaran pesan atau pertukaran informasi. Dengan demikian, dalam rangka penyelenggaraan program komunikasi seperti pemasaran, kampanye, pencitraan ataupun kegiatan pemberdayaan dan kerja sama, harus berpedoman pada kebijakan yang telah disusun. Ini dilakukan untuk mengantisipasi kemungkinan perencanaan yang disusun tidak sesuai dengan kebijakan yang telah digariskan. Oleh karena itu, melihat perencanaan komunikasi harus memperhatikan kebijakan komunikasi atau aturan-aturan 
yang telah dibuat oleh pihak-pihak yang berkaitan.

Perencanaan merupakan salah satu fungsi manajemen. Oleh karena itu, tidak heran jika dalam kajian perencanaan komunikasi, perencanaan dilihat dari aspek manajemen. Menurut (Wheelen \& Hunger, 2004: 68), perencanaan didefenisikan sebagai proses untuk menetapkan hasil akhir yang ingin dicapai pada awal kegiatan. Hal ini menunjukkan bahwa organisasi telah merumuskan capaian hasil sebelum program tersebut dilaksanakan. Ini berarti dalam sebuah perencanaan, para penyusunnya telah mengetahui seperti apa keberhasilan sebuah program. Selain itu, menurut Koontz dan Weirich dalam (Solihin, 2012: 4), perencanaan didefinisikan sebagai suatu proses untuk mengembangkan tujuan-tujuan perusahaan yang mencakup pada penetapan tujuan, mengembangkan berbagai kemungkinan mengenai lingkungan dimana berkaitan dengan tujuan yang ingin dicapai sebuah organisasi, menentukan tindakan yang tepat dalam mencapai tujuan organisasi, merumuskan berbagai aktivitas yang diperlukan untuk menerjemahkan rencana menjadi sebuah tindakan nyata serta melakukan pengulangan tahapan diatas untuk mengoreksi dan mengetahui berbagai kekurangan. Melalui definisi ini, perencanaan dianggap sebagai kegiatan yang terencana dan sekaligus didapatkan dari aktivitas evaluasi dari perencanaan yang sudah didesaian sebelumnya. Dengan kata lain, perencanaan dianggap sebagai sebuah ramalan terhadap kegiatan yang akan dilakukan.

Begitu runtutnya aktivitas yang dilakukan pada tahapan perencanaan, tidak mengherankan jika berbagai organisasi baik perusahaan maupun badan publik melakukan aktivitas perencanaan ini dengan membuat jeda waktu. Ada perencanaan yang memang sengaja dibuat untuk waktu yang pendek, menengah, ataupun untuk waktu yang panjang. Adapun jangka waktu perencanaan dibuat dengan disesuaikan dengan jenis industri maupun organisasinya. Jika kita melihat pada perencanaan program pemerintah, maka biasanya dilakukan dalam jangka waktu menengah. Dikatakan menengah karena perencanaan dilakukan untuk penyelesaian program-program dengan durasi waktu antara 4 sampai 10 tahun (Cangara, 2013: 27).

Meskipun perencanaan dilakukan secara detail dan runut, tidak tertutup kemungkinan perencanaan yang didesain tersebut mengalami kegagalan dalam pelaksanaannya. Dadang Solihin (dalam Cangara, 2013: 28), merumuskan empat kemungkinan besar yang menyebabkan sebuah rencana yang telah disusun dapat mengalami kegagalan. Pertama, kegagalan dalam penyusunan perencanaan yang meliputi, pengumpulan informasi yang kurang, metodologi yang tidak dipahami, tidak realistis, dan implementasi yang tidak sesuai. Kedua, kegagalan dalam pelaksanaan perencanaan yang meliputi, pelaksanaan yang tidak sesuai dengan dokumen rencana, pelaku pelaksana perencanaan yang tidak kompeten, serta tidak adanya dukungan dari stakeholder. Ketiga, kegagalan karena konsep perencanaan yang tidak sesuai dengan kondisi dan perkembangannya. Keempat, kegagalan karena paradigma yang menganggap jika sesuatu telah direncanakan, maka semuanya akan berhasil sehingga mengabaikan pengembangan kapasitas maupun potensi yang ada. Adapun tujuan 
dibuatnya perencanaan aktivitas sematamata untuk panduan bagi semua pihak sekaligus meyakinkan setiap organisasi bahwa perencanaan pun perlu dilakukan evaluasi karena perencanaan pun tidak luput dari kegagalan.

Perencanaan yang telah didesain perlu memerlukan sumber daya untuk mengimplementasikannya agar tidak terjadi kegagalan sehingga tujuan sebuah organisasi dapat tercapai. Salah satu sumber daya yang dimaksud adalah komunikasi. Di sini, komunikasi memposisikan diri sebagai aspek yang menyebarkan informasi dari setiap rencana yang telah disusun dan yang akan dijalankan. Komunikasi mengambil peran untuk menentukan komunikator atau penyampai pesan hingga komunikasi berkontribusi pada saluran dan medium yang digunakan dalam melaksanakan setiap program yang telah direncanakan. Oleh karena itu, tidak mengherankan jika komunikasi dilihat sebagai sebuah sistem yang kompleks.

Komunikasi sebagai sebuah sistem (Cangara, 2013:36) berkaitan erat dengan segala unsur yang dimiliki untuk mendukungnya. Artinya, pesan ada karena ada sumber, media ada karena adanya pesan, dan penerima ada karena adanya pengirim, dan adanya efek serta umpan balik karena adanya penerima, dan seterusnya.

Everett M.Rogers memberikan definisi komunikasi sebagai sebuah proses dimana suatu ide dialihkan dari sumber kepada suatu penerima atau lebih, dengan maksud untuk mengubah tingkah laku mereka. Fokus definisi yang disampaikan oleh Rogers adalah pada terjadinya perubahan perilaku dari keterlibatan pelaku komunikasi. Hal ini berarti menunjukkan begitu kuatnya peran komunikasi dalam hal membuat perubahan. Oleh karena itu, konsep perencanaan komunikasi ini muncul untuk menghubungkan rencana yang telah dibuat dengan menggabungkan segala unsur-unsur yang dimiliki komunikasi. Menurut (Cangara, 2013: 41), perencanaan komunikasi dimaksudkan untuk mengatasi rintangan-rintangan yang ada guna mencapai efektivitas komunikasi, sedangkan dari sisi kegunaan dan fungsi perencanaan komunikasi untuk mengimplementasikan program-program yang ingin dicapai baik kegiatan kampanye, penyuluhan, pencitraan, pemasaran social dan komersial, maupun untuk pembangunan infrastruktur komunikasi.

Dari uraian di atas, dapat disimpulkan bahwa perencanaan komunikasi merupakan sebuah dokumen tertulis yang berisikan tentang apa yang harus dilakukan yang berhubungan dengan komunikasi dalam mencapai tujuan. Program komunikasi itu untuk mengetahui kepada siapa program komunikasi itu ditujukan, mengunakan alat apa dan memerlukan waktu berapa lama untuk mencapai semua itu, dan untuk mengetahui hasil yang diperoleh sebagai bahan evaluasi. Hal ini berarti bahwa segala komponen komunikasi untuk berlangsungnya sebuah komunikasi menjadi hal penting dalam perencanaan komunikasi. Perencanaan komunikasi dijadikan sebagai penuntun usaha atau kegiatan komunikasi yang dilakukan sepanjang program tersebut dilaksanakan. Selain itu, perencanaan komunikasi juga membantu untuk menggunakan saluran dan waktu yang tepat dalam menyebarkan pesan. Dengan kata lain, perencanaan 
komunikasi akan menjadi pegangan bagi para stakeholders untuk selalu wellinformed, terutama dalam kaitannya dengan apa yang ditawarkan.

Fergusson (1999: 43) lebih lanjut mengemukakan bahwa perencanaan komunikasi pada dasarnya merupakan dokumen penting yang berisikan rencana strategis organisasi dalam menjalankan program bisnisnya maupun dokumen yang digunakan dalam hal penyelesaian masalah yang dihadapi di lapangan. Lebih lanjut, Fergusson memetakan tiga tahapan untuk memulai perencanaan komunikasi sebagai berikut.

1. Proses Perencanaan harus meliputi who, how dan when.

who berkaitan dengan siapa yang akan menyusun perencanaan komunikasi tersebut. Idealnya, perencanaan komunikasi disusun oleh setiap pihak yang berkaitan dengan program yang akan dijalankan seperti pimpinan dalam sebuah organisasi, divisi public relations, divisi marketing komunikasi, dan unit-unit lainnya yang memiliki kepentingan untuk menjalankan program. Setelah perencanaan komunikasi disusun, maka who ini berkaitan dengan siapa pihak yang akan ditunjuk sebagai komunikator yang tepat dalam penyampaian pesan. Tentunya, pemilihan komunikator ini didasarkan pada kompetensi yang dimiliki. Menurut Kinkead \& Winokur dalam (Fergusson, 1999: 22), individu yang tepat sebagai komunikator ini adalah orang yang bisa memberikan pengaruh pada lingkungan internal dan eksternal organisasi, sedangkan how berkaitan dengan hal-hal prinsip untuk menuliskan perencanaan, mulai dari pertimbangan jangka waktu, menuliskan perencanaan sesuai dengan perspektif organisasi. When berkaitan dengan alokasi waktu yang tepat untuk menyusun perencanaan komunikasi tersebut.

2. Perencanaan komunikasi memiliki prinsip penyesuaian

Bagian ini menjelaskan bahwa perencanaan komunikasi yang dibuat harus mempertimbangkan waktu dan kebutuhan serta perkembangan lingkungan internal dan eksternal organisasi. Dengan kata lain, perencanaan komunikasi harus mampu beradaptasi dengan segala perubahan.

3. Tahapan membuat perencanaan komunikasi yang dimulai dari analisis situasi, memahami lingkungan baik internal maupun eksternal, tujuan komunikasi, pesan, medium hingga anggaran biaya yang dibutuhkan.

Selain tahapan di atas, ada banyak model yang digunakan dalam studi perencanaan komunikasi. Namun, penggunaan model dan tahapan perencanaan komunikasi tersebut ditentukan oleh situasi dan kondisi dari organisasi tersebut.

\section{Metode Penelitian}

Metode yang digunakan dalam penelitian ini adalah metode kualitatif, berupa penelitian deskriptif induktif dengan menganalisis dan mengeksplorasi secara mendalam fenomena yang menjadi minat penelitian ini terutama dalam bidang kajian perencanaan komunikasi. Penelitian kualitatif sendiri merupakan penelitian yang bermaksud untuk memahami fenomena tentang apa yang dialami oleh subjek penelitian dengan cara deskriptif dalam bentuk kata-kata dan 
bahasa, pada suatu konteks khusus yang alamiah dan dengan memanfaatkan berbagai metode ilmiah (Moleong, 2005: 6).

Pada Penelitian ini, narasumber ditentukan melalui teknik purposive sampling. Penelitian dilakukan dari bulan November 2015 hingga Maret 2016. Adapun narasumber penelitian ini terdiri dari Kepala Badan Perencanaan Daerah, Staf Bidang Renstra Bapedda, Sekretaris Umum Dinas Komunikasi, dan Informatika Kota Palembang, Assisten Pemerintahan Bagian Hubungan Masyarakat Kepala Bagian Hubungan dan Media. Adapun teknik pengumpulan data dilakukan melalui wawancara, observasi, serta studi dokumentasi, sedangkan untuk teknik keabsahan data dilakukan dengan cara triangulasi.

\section{HASIL DAN PEMBAHASAN \\ Perencanaan Komunikasi \\ Kampanye Palembang Emas}

Perencanaan komunikasi yang
dilakukan oleh Pemerintah $r$ Kota
Palembang dilakukan melalui dua
komponen, yaitu organisasi dan publik.
Organisasi sebagai pengelola kegiatan
dalam hal ini pemerintah Kota
Palembang, sedangkan publik adalah yang
menjadi sasaran kegiatan dari organisasi
tersebut yang meliputi masyarakat, pasar
maupun wisatawan.

\section{Organisasi sebagai Pengelola Kegiatan}

a. Analisis Situasi dan

Perumusan Kebijakan oleh Pemerintah Kota Palembang

Dari hasil penelusuran dokumentasi yang dimiliki oleh pemerintah Kota Palembang dan wawancara yang dilakukan peneliti kepada pihak yang terkait dalam penelitian ini, disebutkan bahwa Palembang EMAS selain menjadi sebuah brand Kota Palembang, sekaligus juga menjadi visi pembangunan Kota Palembang tahun 2013-2018. Secara historis, EMAS (Gold) merupakan lambang Kerajaan Sriwijaya atau masa keemasan Kerajaan Sriwijaya sehingga secara sosiologis dengan visi Palembang EMAS, dicita-citakan kondisi masyarakat Kota Palembang untuk mencapai kondisi terbaik dalam kemakmuran dan kejayaan. Selain diterjemahkan dari sudut pandang historis dan sosiologis, kata EMAS merupakan pernyataan kondisi yang ingin dicapai oleh Pemerintah Kota Palembang dalam lima tahun mendatang. Kondisi yang ingin dicapai tersebut merupakan kepanjangan dari setiap huruf pada kata EMAS, yaitu "Elok, Madani, Aman dan Sejahtera". Berikut penjelasan masingmasing hurup dari kata EMAS yang dimaksud.

1) Elok

Elok berarti bersih, indah dan menawan. Kata Elok di sini artinya adalah Kota Palembang harus memiliki lingkungan hunian dengan penampilan yang bersih, indah sehingga menawan untuk dilihat. Masyarakatnya ramah, bersahabat, aman dan menarik untuk orang melakukan berbagai aktivitas kehidupan baik aktivitas ekonomi/bisnis, politik, pendidikan, kesehatan, olahraga, budaya, wisata dan pengembangan teknologi inovasi dan kreatif.

2) Madani

Madani berarti masyarakat yang menjunjung tinggi norma, nilai- 
nilai, dan hukum, yang ditopang oleh penguasaan teknologi, beradab, beriman dan berilmu. Madani di sini adalah masyarakat Kota Palembang yang tertib dan aman karena patuh kepada peraturan yang berlaku, memiliki peradaban yang tinggi karena mengedepankan kesederajatan, transparansi dan demokrasi, berkeadilan sosial karena memiliki toleransi dalam pluralisme, partisipasi sosial yang luas dan supremasi hukum.

3) Aman

Situasi aman dan tertib merupakan kondisi yang mutlak diperlukan, dimana masyarakat Kota Palembang terbebas dari segala gangguan yang mengancam ketentraman kehidupan dan aktifitas masyarakat. Dengan terwujudnya rasa aman, maka seluruh masyarakat dapat melaksanakan aktifitas dan memperoleh kebutuhan dasarnya dalam suasana kondusif yang pada akhirnya juga menarik dunia usaha untuk menanamkan modalnya di Kota Palembang.

4) Sejahtera

Sejahtera mengandung arti makmur dan berkeadilan, artinya adalah Kota Palembang harus jaya atau adil makmur dan sejahtera baik lahir maupun batin. Masyarakat Kota Palembang harus sehat jasmani dan rohani, memilik kecukupan ekonomi, terpenuhinya hak-hak dasar hidup manusia dalam bidang pendidikan, kesehatan, ketentraman, ketertiban dan keadilan sosial. (Dokumen RPJMD Kota Palembang 2013-2018)

Sebagai sebuah organisasi dalam hal ini pemerintah kota melakukan tahapan awal dalam sebuah perencanaan komunikasi dengan memetakan potensi yang dimiliki oleh Kota Palembang kemudian menuangkannya menjadi sebuah kebijakan tertulis oleh pemerintah melalui visi dan misi pembangunan Kota tahun 2013-2018. Seperti diuraikan (Fergusson, 1999: 43), perencanaan komunikasi pada dasarnya merupakan dokumen penting yang berisikan rencana strategis organisasi dalam menjalankan program bisnisnya maupun dokumen yang digunakan dalam hal penyelesaian masalah yang dihadapi di lapangan. Khusus pada point ini sebenarnya pemerintah kota sudah melakukan tahapan analisis dan riset sebagai langkah awal untuk mendiagnosa atau mengetahui permasalahan yang dihadapi.

Potensi tersebut dicantumkan dalam sebuah slogan yang mengandung makna dari setiap huruf yang disingkat yang ditujukan untuk publik internal maupun eksternal. Publik internal yang dimaksud di sini adalah masyarakat Kota Palembang yang direpresentasikan pada slogan elok dan sejahtera. Selanjutnya, slogan yang ditujukan untuk publik eksternal dalam hal ini investor, wisatawan, dsb, yaitu, point madani dan aman. Melalui point madani, pemerintah Kota Palembang sedang berusaha untuk "menjual" kotanya kepada para investor maupun wisatawan, dimana Palembang merupakan kota dengan masyarakat yang sangat bersahabat, serta menjunjung tinggi nilai. Aman, di sisi lain, menunjukkan bahwa Kota Palembang merupakan kota yang yang layak untuk dijadikan sebagai tempat aktivitas bisnis maupun kota yang memberikan jaminan dalam berwisata. Melalui kata EMAS, pemerintah Kota Palembang telah melakukan analisis terkait dengan nilai 
lebih apa yang akan diberikan suatu destinasi kepada wisatawan maupun investor. Jadi, apabila pesan tersebut adalah brand destinasi, maka pesan itu akan menjadi "datang ke sini, dan kamu akan mendapatkan apa yang kamu inginkan" (Bungin, 2015: 46).

Kebijakan komunikasi tidak dapat dipisahkan dari visi dan misi pembangunan daerah. Visi Kota Palembang adalah Palembang Elok, Madani, Aman, dan Sejahtera (Palembang EMAS). Sementara itu, misi Kota Palembang adalah sebagai berikut.

1) Menciptakan tata kelola pemerintahan yang amanah dan berwibawa serta peningkatan pelayanan masyarakat.

2) Menciptakan Kota Palembang lebih aman untuk berinvestasi dan mandiri dalam pembangunan.

3) Meningkatkan ekonomi kerakyatan melaluipemberdayaan masyarakat.

4) Mendorong keimanan dan ketakwaan masyarakat sehingga terciptanya masyarakat yang religius.

5) Meningkatkan pembangunan yang adil dan berwawasan lingkungan di setiap sektor.

6) Meningkatkan Pembangunan Kota Palembang yang elok, sebagai Kota metropolitan bertaraf internasional, beradat dan sejahtera.

(Sumber: Dokumen Rencana Pembangunan Jangka Menengah Daerah (RPJMD) Kota Palembang 2013-2018)

Poin-poin dalam visi dan misi tersebut merupakan kerangka dasar pembangunan Kota Palembang. Oleh karena itu, semua program pemerintah daerah disingkronkan dengan ke 6 (enam) misi tersebut sehingga masing-masing SKPD dalam merumuskan perencanaan strategi mengarah pada pedoman tersebut.

Dalam hal keterkaitan kebijakan komunikasi kampanye Palembang EMAS pada kebijakan umum pemerintah daerah, poin kebijakan komunikasi nampak pada program pembangunan untuk mewujudkan Misi ke 2 (dua), yaitu tentang menciptakan Kota Palembang lebih aman untuk berinvestasi dan mandiri dalam Pembangunan sebagai poin kebijakan umum. Hal ini sejalan dengan tujuan awal dari aktivitas branding kota. Setiap kota berusaha untuk menjual kotanya melalui nama, istilah, simbol maupun tanda kota sehingga menarik investor maupun wisatawan. Dalam kepentingan itu, Pemerintah Kota Palembang menjual istilah "aman" sebagai brand kotanya, sebagai identitas dari kota tersebut

Kebijakan komunikasi lainnya tercantum pada poin ke-6 (keenam) tentang program pembangunan daerah informasi dan media massa. Sasaran program ialah tersebar dan meratanya informasi pembangunan kepada masyarakat. Arah kebijakan mengarah pada penguatan pelayanan publik berbasis teknologi informasi yang di fokuskan pada penguatan sistem informasi di setiap kecamatan. Selain itu, penguatan pada jaringan informasi, program kerjasama informasi dengan media massa, kajian penelitian bidang komunikasi dan informatika, pelatihan dan pengembangan Kelompok Informasi Masyarakat (KIM) di setiap kecamatan. Program tersebut ditanggungjawabi oleh Satuan Kerja 
Perangkat Daerah (SKPD) Dinas Komunikasi dan Infotmatika.

Meski untuk tahapan awal dilakukan baik oleh Pemerintah Kota Palembang, peneliti mencatat sedikit kekurangan dalam hal penggunaan slogan EMAS tersebut. Aktivitas mem-branding kota bukanlah aktivitas yang muncul tibatiba. Perlu adanya perencanaan dan keberlanjutan. Brand sebuah kota bukan hanya sekedar kebijakan 5 tahunan. Jika EMAS juga dikatakan sebagai merek Kota Palembang oleh beberapa narasumber dalam penelitian ini, maka kebijakan ini seharusnya menjadi program komunikasi untuk jangka waktu yang panjang. Ini dimaksudkan agar, brand yang dibuat tidak menimbulkan kebingungan (confusion) kepada seluruh layer yang menafsirkan brand tersebut.

\section{b. Perencanaan Program}

\section{Kampanye Palembang EMAS}

Palembang EMAS merupakan hasil kesepakatan capaian tujuan yang menjadi prioritas pembangunan di Kota Palembang. Palembang EMAS menjadi dasar tujuan pembangunan daerah khususnya Kota Palembang. Hal tersebut merupakan payung perencanaan program pemerintah dalam mewujudkan visi pembangunan jangka menegah daerah sesuai perencanaan jangka panjang daerah dan perencanaan pembangunan nasional.

Kebijakaan komunikasi kampanye pembangunan daerah Kota palembang diintegrasikan dalam dokumen perencanaan pembangunan daerah. Pemerintah Kota Palembang memiliki dokumen perencanaan pembangunan yang dijadikan kerangka dasar penentuan strategi dan kinerja satuan kerja perangkat daerah (SKPD). Dokumen tersebut berupa dokumen yang di tulis pada dokumen Rencana Pembangunan Jangkah Menengah Daerah (RPJMD) Kota Palembang tahun 2013-2018 sehingga semua unsur rencana pembangunan dituangkan kedalam dokumen perencananan tersebut yang dijadikan asas atau pedoman dalam melakukan kinerja. Ada tiga tahapan perencanaan program pelaksanaan yang dilakukan oleh Pemerintah Kota Palembang. Pertama, menyiapkan fasilitas dengan membuat sistem administrasi daerah yang berbasis teknologi informasi. Tahapan pertama ini juga berusaha untuk mengoptimalkan jaringan dan media informasi yang ada di masyarakat maupun lembaga penyiaran. Kedua, menyiapkan dana. Ketiga, menyiapkan Sumber Daya Manusia (SDM). Untuk mendukung kampanye Palembang EMAS, pemerintah Kota Palembang menyadari bahwa tidak cukup hanya dengan membuat kebijakan dan menyediakan anggaran saja, akan tetapi tenaga penggerak pun perlu dipertimbangkan. Beberapa persiapan yang telah dilakukan pemerintah Kota Palembang untuk menguatkan SDM ini adalah melakukan pelatihan di bidang penyiaran dan kelembagaan komunikasi.

\section{c. Kegiatan Komunikasi}

Pada dasarnya, pencanangan kata EMAS pada Palembang EMAS bukan hanya untuk penyebarluasan informasi terkait pemerintahan saja, tetapi juga sebagai media promosi Kota. Filosofi EMAS yang termaksud dalam visi dan misi pemerintah tersebut berakar pada nilai sejarah dan potensi pariwisata yang berada di Kota Palembang. Palembang EMAS menjadi spirit pembangunan pemerintah daerah dalam membawa 
pemerintahan. Hal ini dapat dijumpai dibeberapa media reklame dan baliho yang mengusung pesan kampanye dalam kalimat "mari bersama wujudkan Palembang EMAS". Kata-kata tersebut menjadi unsur kampanye karena bersifat persuasi, mengajak dan menghimbau. Sasaranya tentu adalah masyarakat Kota Palembang dan wisatawan yang berkunjung ke Palembang.

"Upaya upaya yang dilakukan untuk mewujudkan semua itu ialah memberikan informasi seluas luasnya, tentang investasi, tentang hasil pembangunan, potensi, tata kelola, pelayanan publik yang diutamakan. Kepada masyarakat yang sifatnya sudah digital atau pelayanan yang cepat dan akurat. Contohnya pelayanan publik di KPPT tempat Perizinan Terpadu, kemudian di kecamatan dan keluarahan. Diskominfo memiliki peran menyebarluaskan kepada masyarakat agar masyarakat mengetahui kebijakan agar mempermudah hajatnya dengan baik. Menyebarluaskan informasi kepada seluruh masyarakat" (Subari, Sekretaris Dinas Komunikasi dan Informatika Kota Palembang, Wawancara, Kamis, 17 Desember 2015). Berikut adalah kegiatan komunikasi dalam kampanye Palembang EMAS.

1) Komunikasi Tatap Muka

Program komunikasi ini adalah semacam program wajib Walikota. Selain sosialisi, Walikota sering mengadakan kunjungan langsung kekelurahan dan kecamatan dengan berbagai macam segmentasi. Kunjungan bukan hanya fokus terhadap bidang kepemerintahan, tetapi kunjungan lebih kepada pendekatan kepada masyarakat. Ada dua program kunjungan masyarakat yang dilakukan Walikota. Pertama, program "Ngantor Walikota" berupa kunjungan kerja Walikota ke kelurahan dan kecamatan untuk meninjau situasi dan kondisi terkait pelaksanan kinerja pemerintah dan juga sebagai peninjauan terhadap program prioritas Walikota dalam rangka mewujudakan Palembang Emas.

2) Komunikasi Melalui Media Luar Ruang

Program komunikasi media luar ruang ialah dengan memanfaatkan reklame atau billboard, spanduk, dan leaflet, Pesan komunikasi berupa pesan ajakan untuk membangun Palembang Emas. Hasil catatan observasi menunjukan bahwa kota Palembang lebih banyak memanfaatakn media reklame. Ini karena hampir diseluruh sudut kota terdapat reklame besar yang terus di perbaharui sesuai pesan komunikasi terbaru berupa ajakan terhadap suatu hal, misalnya, pesan ajakan untuk membuat izin mendirikan bangunan (IMB) dengan latar belakang pesan "Palembang Emas" yang pada dasarnya adalah pesan persuasif yang ditujukan kepada seluruh masyarakat. 


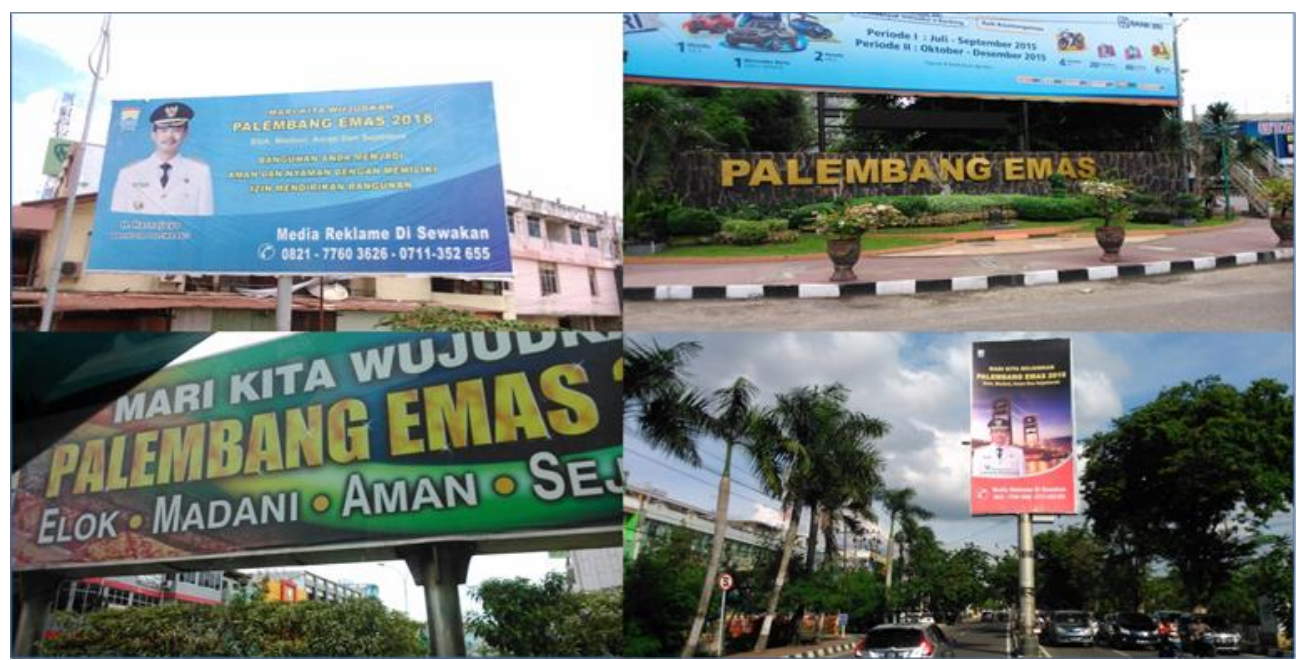

Gambar 1. Pesan Palembang EMAS melalui Media Luar Ruang

Melalui media luar ruang, pemerintah Kota Palembang sedang melakukan teknik penyampaian pesan yang bersifat persuasif. Komunikasi persuasif berusaha mengubah pengetahuan, sikap, tingkah laku seseorang atau public terhadap program yang akan dilaksanakan. Adapun pesan yang disampaikan melalui media luar ruang tersebut menggunakan teknik persuasi penyusunan pesan yang penuh dengan dorongan. Dimana teknik penyusunan pesan yang dibuat bukan karena janji-janji melainkan disusun untuk mempengaruhi internal psikologis publik (Cangara, 2013: 118)

3) Komunikasi Melalui Media Internal Pemerintah
Seluruh kegiatan pemerintah baik pra kegiatan dan pascakegiatan dimuat di dalam media internal pemerintah, berupa bulletin yang diterbitkan 1 (satu) bulan sekali. Isinya berkaitan dengan laporan kegiatan pemerintah yang diramkum sedimikian rupa untuk dibagikan keseluruh instansi pemerintah. Berita tersebut akan membawa pesan terhadap hasil program yang telah dilaksanakan apakah sudah tercapai maksimal atau belum berdasarkan opini masyarakat. Sehingga dengan begitu media internal dapat membantu pemerintah dalam mengawasi kegiatan atau program yang dibuat dan direncanakan.

4) Komunikasi melalui media baru Kehadiran internet telah membawa harapan baru bagi sebuah Negara maupun kota. 
Melalui beragam aplikasi yang ditawarkan, akan semakin memudahkan proses transfer pesan. Begitupun yang dilakukan pemerintah kota Palembang dalam kampanye Palembang EMAS. Medium seperti webstie, twitter, facebook dimanfaatkan untuk penyebarluasan pesan maupun untuk menjaring peran serta dan keterlibatan masyarakat. Penggunaan masingmasing medium tersebut disesuiakan dengan masyarakat yang dituju.

5) Komunikasi melalui media massa Pemerintah Kota Palembang melakukan kemitraan dengan media massa. Setiap wartawan media massa dibina untuk membantu pemerintah menyebarluaskan informasi terkait kegiatan program pemerintah melalui media massa. salah satu medianya adalah media Televisi. Televisi adalah media yang paling dekat dengan masyarakat. Keuntunganya terdapat dalam televisi menyajikan pesan secara visual sehingga masyarakat dapat lebih mudah memahami pesan

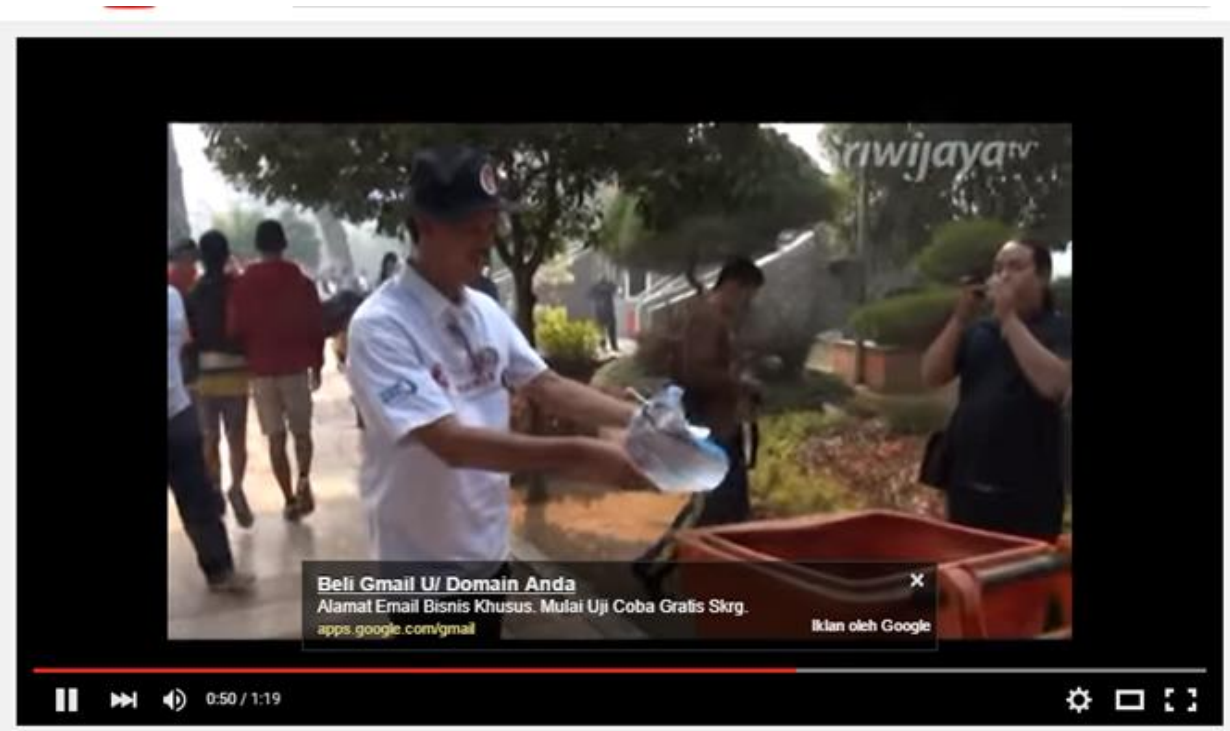

Harnojoyo Menghimbau Warga Menjaga Kebersihan Agar Palembang Emas Terwujud

Gambar 2. Komunikasi melalui Sriwijaya TV 
Sebagian besar urusan komunikasi pemerintah dikelola oleh Dinas Komunikasi dan Informatika Kota Palembang. Dinas Komunikasi dan Informatika (Diskominfo) Kota Palembang adalah yang sebagaimana tugas dan fungsinya adalah melakaksanakan programprogram komunikasi pemerintah secara khusus. Seperti kebijakan terhadap pemilihan media luar ruang, surat kabar, tv dan radio (media massa), internet (media barru) dalam pelaksanaan program komunikasi kampanye Palembang Emas disamping bersinergi dengan SKPD lainya. Untuk informasi terkait program pemerintah diperoleh dari satu sumber atau satu pintu yakni berasal dari bagian Humas pemerintah sehingga humas dan Diskominfo pada umumnya saling bersinergi terhadap pelaksanan komunikasi kampanye Palembang EMAS.

\section{Publik sebagai Sasaran kegiatan Kampanye Palembang EMAS}

\section{a. Feedback}

Publik adalah komponen penting yang menjadi sasaran kegiatan organisasi. Salah satu aktivitas yang dilakukan oleh pemerintah kota dalam rangka kampanye Palembang EMAS adalah melibatkan masyarakat dalam aktivitas penyebaran pesan melalui media sosial dan mendapatkan umpan balik melalui focus group discussion (FGD) yang rutin dilaksanakan mulai dari kelurahan hingga kecamatan. Meski dalam perjalanannya, ditemukan sekelompok masyarakat yang belum memahami Palembang EMAS tersebut. Akan tetapi usaha yang dilakukan pemerintah kota Palembang untuk melibatkan masyarakat patut diapresiasi.

"Semuanya punya rencana, dalam mewujudkan visi dan misi itu setiap SKPD itu punya tugas masing-masing sesuai dengan tugas dan fungsi. Tidak sendiri! Jadi bukan hanya Bappeda yang memegang peranan dalam mewujudkan visi misi, tapi setiap SKPD memiliki tanggung jawab dan tugas masing masing sesuai dengan tufoksinya. Masyarakat juga berperan penting dalam mewujudkan itu semua, tanpa dukungan masyarakat semua program akan percuma (Sapri, Wawancara, Kepala Badan Perencanaan Bappeda Palembang, Selasa, 15 Desember 2015).

\section{Evaluasi}

Evaluasi Program adalah serangkaian hasil analisis terhadap program yang telah direncanakan. Pemerintah kota Palembang sendiri melaksanakan evaluasi berdasarkan tiga macam program evaluasi. Evaluasi tahunan, semester, dan triwulan. Evaluasi tahunan biasanya dilakukan untuk evaluasi yang mencangkup keseluruhan program dari setiap wilayah. Indikator evaluasi pertahun berdasarkan Rencana Pembangunan jangka menengah daeah (RPJMD) Kota Palembang. Selanjutnya, evaluasi semester bersifat medium karena jangkauan evaluasi tidak sebesar evaluasi pertahun, karena ranah evaluasi hanya sebatas lingkup SKPD. Terakhir, evaluasi triwulan yang memiliki jangkauan lebih 
sempit karena pembahasan evaluasi secara langsung membahas terhadap program pelaksanaan yang sedang berlangsung. Setiap program evaluasi tersebut bermuara pada publik yang menerima dampak dari program yang dilakukan oleh pemerintah Kota Palembang.

\section{PENUTUP}

Hasil penelitian ini menunjukkan bahwa perencanaan komunikasi yang dilakukan oleh pemerintah Kota Palembang dalam kampanye Palembang EMAS terdiri atas dua langkah utama yai,tu penguatan organisasi yang menggerakkan kegiatan dan publik yang menjadi sasaran kegiatan. Adapun langkah-langkah yang dilakukan dalam komponen organisasi terdiri dari analisis situasi. Kemudian, melalui analisis tersebut diturunkan dalam sebuah rumusan kebijakan Palembang EMAS. Selanjutnya, setelah dilakukan perumusan kebijakan, pemerintah Kota Palembang melakukan perencanaan progam dimana didalamnya telah termasuk penetapan anggaran, SDM, maupun fasilitas lainnya. Langkah terakhir dalam komponen organisasi adalah melakukan kegiatan komunikasi baik dilakukan secara tatap muka maupun komunikasi melalui beragam media sepeti media luar ruang, media massa, maupun social media. Selanjutnya, pada komponen publik, dilakukan langkah feedback dan evaluasi. Umpan balik didapatkan melalui aktivitas focus group discussion (FGD), sedangkan evaluasi dilakukan secara triwulan, semester dan tahunan. Dimana hasil evaluasi ini menjadi pertimbangan dalam pengambilan keputusan dalam rangka perbaikan, peningkatan maupun penyusaian program kampanye Palembang EMAS.

\section{Daftar Pustaka}

Bungin, Burhan. 2015. Komunikasi Pariwisata. Jakarta: Prenada Media Group

Cangara, Hafied. 2013. Perencanaan Komunikasi. Jakarta: Rajagrafindo Persada

Ferguson, Sherry Devereaux. 1999. Communication Planning an Integrated Approach. London: Sage Publications

\section{Moleong, Lexy J. 2005. Metodologi} Penelitian Kualitatif. Bandung: Ramaja Rosdakarya
Solihin, Ismail. 2012. Manajemen Strategik. Jakarta: Erlangga

Wheelen,T.L., \& Hunger,D.J. 2004. Strategic Management and Bussines Policy, Ed 9. United States: Prentice Hall

Sumber lain:

RPJMD. (2013). Rencana Pembangunan Jangka Menengah Daerah (RPJMD) Kota Palembang Tahun 2013-2018. Palembang: Bappeda Kota Palembang 
Jurnal komunikasi, Volume 10, Nomor 2, April 2016 